\title{
YOUTH EVENT MANAGEMENT POTENTIAL AND SOCIAL DEVELOPMENT IN CHANGING WORLD*
}

\author{
Zhanna Semchuk ${ }^{1}$, Bohdan Koshovyi ${ }^{2}$, Ruslana Kramar ${ }^{3}$
}

Received: 2021-06-04

Accepted: 2021-07-04

DOI: http://doi.org/10.46489/gpj.2021-1-2-2

Abstract. In this article, we have considered the complex problem of developing and realizing the potential of young people in the light of the challenges that arise in the modern world. Young people are a vulnerable social group for whom state and local support is essential. Problems in employment can shake the incentive for young people to develop their potential. We investigated the impact of educational and social space on the development of one of the components of youth potential - potential in event management. We emphasized that the development of this component can be a good impetus for intensifying the entrepreneurial activity of young people. However, youth employment and entrepreneurship in event management need care from the state and intensification of informal social control mechanisms. We have formed recommendations that will allow integrating the processes of social development and development of youth potential in event management. This work can be helpful for public authorities, educational institutions and public organizations.

Keywords: youth, potential, development of potential, event management potential, social control.

\footnotetext{
${ }^{*}$ To prevent conflicts of interest, the Chairman of the Editorial Board managed the entire editorial process for this article according to the ethical standards of Global Prosperity (http://gprosperity.org/index.php/journal/pol)

1 Zhanna Semchuk, D. Sc. (Economics), Professor, Dean of the Faculty of Economics and Business, Lviv University of Business and Law, Kulparkivska str., 99, Lviv, Ukraine, ORCID: https://orcid.org/0000-0002-4868-7716

2 Bohdan-Petro Koshovyi, PhD, Head of the Department of Demography, Labor Relations and Social Policy, Lviv University of Business and Law, Kulparkivska str., 99, Lviv, Ukraine, qqbkqq@gmail.com, ORCID: https://orcid.org/0000-0001-8550-0028

3 Ruslana Kramar, PhD, Associate Professor, Head of the Department of Judiciary, Prosecutory and Advocacy, Lviv University of Business and Law, Kulparkivska str., 99, Lviv, Ukraine, ORCID: http://orcid.org/0000-00015086-9845
} 


\section{ВСТУП}

Особливе місце у системі управління соціальним розвитком належить підсистемі управління соціальним розвитком молоді.

Молодь $\epsilon \quad$ специфічною демографічною групою, що об’єктивно обмежується рамками переходу від стану дитячої залежності до дорослої незалежності (Резолюції Генеральної асамблеї $\quad 00 \mathrm{~A} \quad \mathrm{~A} / \mathrm{RES} / 50 / 81$, A/RES/56/117, A/RES/62/126). Відповідно, динаміка соціального розвитку молоді поступово (а іноді стрімко) виходить з-під контролю батьків чи опікунів і опиняється у залежності від особистісних характеристик молодої особи. Таким чином, відповідальність за вирівнювання динаміки соціального розвитку молоді має взяти на себе держава як інститут найвищого авторитету. Ефективність державної політики за цим напрямком визначає вихідну позицію соціального розвитку дорослої особи, здобуту унаслідок попереднього розвитку у процесі їі становлення в рамках належності до групи молоді.

\section{Демографічна} характеризується потребами (освіта, охорона здоров'я (зокрема, у сфері дітонародження, здорового харчування, попередження шкідливих звичок), безпека (у зв'язку з підвищеними ризиками девіантної та деліквентної поведінки), житло, духовні потреби, розваги тощо). У зв'язку 3 переважно недостатнім фінансовим забезпеченням, у повній мірі задовольнити потреби молоді, необхідні для подальшого соціального розвитку, може тільки держава.

Молодь $\epsilon$ ключовим об'єктом управлінських впливів у сфері формування трудового потенціалу. Основа подальшої трудової діяльності більшості дорослого населення закладається у молодіжному віці. Ефективність соціального розвитку у частині формування трудового потенціалу молоді слід оцінювати також крізь призму здатності держави забезпечити молодих фахівців гідним місцем праці і таким чином уникнути невиправдної трудової міграції.

Проголошений соціальний характер української економіки доповнюється традиційним для України культурним феноменом спадковості поколінь концентрація зусиль на розвитку молоді означає здатність молоді у подальшому брати участь у утриманні громадян, котрі досягли пенсійного віку, у фінансуванні розвитку нового покоління молоді і впевненість у майбутньому захисті по досягненню пенсійного віку.

За умови ефективної побудови i функціонування системи соціального розвитку молоді, молодь проявляє себе як рушій суспільних, економічних, політичних перетворень завдяки такій особливій властивості як готовність і відкритість до змін, інноваційне мислення, висока творча і трудова активність.

Одним 3 елементів трудового потенціалу молоді $є$ потенціал у сфері івент-менеджменту. Вибудування соціальних зв'язків молоді на основі цього елементу трудового потенціалу $\epsilon$ передумовою забезпечення сталого економічного і соціального розвитку. Централізована i децентралізована промоція програм з розвитку розуміння i використання навичок івентменеджменту у молоді дозволить досягнути європейських стандартів у сфері соціального розвитку молоді та стане запорукою інтеграції у європейський економічний, освітній та культурний простір.

Метою статmі $є$ обгрунтувати теоретичні засади розвитку і реалізації потенціалу молоді у сфері івентменеджменту. 


\section{РЕЗУЛЬТАТИ}

Станом на сьогодні у сфері регулювання молодіжної зайнятості в Україні спостерігаються значні труднощі, пов'язані не лише 3 проблемами економічного чи політичного характеру, але і 3 недосконалістю методологічних підходів. Bondarevska K. V., Fomenko A. O. (2015) грунтовно дослідили актуальні проблеми молодіжної зайнятості в сучасних умовах і встановили, що пріоритетними проблемами щодо зайнятості молоді, які потребують свого вирішення, $\epsilon$ подолання дисбалансу на ринку праці; створення нових робочих місць; досягнення порозуміння між державою, роботодавцями та молодими фахівцями.

Молодь $\epsilon$ уразливою соціальною групою, для неї недоступні певні уміння та навички, які приходять 3 досвідом. Безперечно, у окремих випадках спостерігаються особи, котрі володіють природженим організаторським хистом та мають природній потенціал у сфері івент-менеджменту, реалізація якого дозволяє без додаткової підготовки вирішити проблеми 3 працевлаштуванням.

Сучасні процеси реформування вищої освіти в Україні скеровуються на досягнення такого рівня якості освіти, за якого здобуті у ході навчання компетенції, у тому числі у сфері івентменеджменту відповідатимуть вимогам роботодавців. Вища освіта - це сукупність систематизованих знань, умінь і практичних навичок, способів мислення, професійних, світоглядних i громадянських якостей, моральноетичних цінностей, інших компетентностей, здобутих у вищому навчальному закладі (науковій установі) у відповідній галузі знань за певною кваліфікацією на рівнях вищої освіти, що за складністю є вищими, ніж рівень повної загальної середньої освіти. Водночас, компетентність визначається як динамічна комбінація знань, вмінь i практичних навичок, способів мислення, професійних, світоглядних і громадянських якостей, морально-етичних цінностей, яка визначає здатність особи успішно здійснювати професійну та подальшу навчальну діяльність і $\epsilon$ результатом навчання на певному рівні вищої освіти (Zakon Ukrainy «Pro vyshchu osvitu»).

3 успішністю подальшої професійної діяльності пов'язуються також терміни «якість вищої освіти» та «результати навчання». Так, якість вищої освіти - це рівень здобутих особою знань, умінь, навичок, інших компетентностей, що відображає її компетентність відповідно до стандартів вищої освіти; результати навчання - це сукупність знань, умінь, навичок, інших компетентностей, набутих особою у процесі навчання за певною освітньо-професійною, освітньо-науковою програмою, які можна ідентифікувати, кількісно оцінити та виміряти. Водночас, на нашу думку, 3 позиції забезпечення подальшої професійної діяльності слід по-іншому трактувати процес здобуття освіти (не тільки вищої). Керуючись спостереженнями за суспільними трендами, інтерв'юванням студентів різних спеціальностей можемо висловити гіпотезу щодо важливості у рамках вищої освіти формування не «компетентностей», а трудового потенціалу молоді, у тому числі й за окремими напрямками, як-от івентменеджмент.

Молодь віком 15 - 24 р. нерідко потребує особливої підтримки щодо першого працевлаштування. $\mathrm{He}$ володіючи досвідом роботи, утім маючи суттєвий потенціал до праці (трудовий потенціал) нерідко молодь у цьому віці стає жертвами «тіньової економіки» працевлаштування на неформальних засадах (без офіційного оформлення). Особливо уразливою $є$ група молоді, котра прагне реалізувати потенціал у сфері івент-менеджменту. Оскільки це відносно нова галузь зайнятості, 
спостерігається брак нормативноправового забезпечення іiї регулювання, що може негативно позначитись на соціальному розвитку та захисті молоді.

В умовах обмеженості ресурсів можливості держави 3 покращення становища молоді $€$ досить обмежені. Утім, слід проводити постійну роботу 3 пошуку нових шляхів підвищення якості життя не зважаючи на складну ситуацію. Соціально-економічна криза, що розгорнулась в Україні, особливо відображається на молоді перетворившись для цієї групи у перманентну кризу. Слід відзначити, що основними напрямками покращення якості життя молоді за категорією фінансових потреб слід вважати стимулювання підприємницької діяльності молоді, завдяки якій уможливиться й реалізація та розвиток потенціалу у сфері івент-менеджменту

Dmytrash O. P., Smyrychynskyi V. V. (2009) наголошують, що в Україні виникла об'єктивна необхідність розробки ефективних механізмів, які б стимулювали працевлаштування молоді i сприяли б розвитку молодіжних підприємницьких ініціатив, що повинно знайти відображення у державній та регіональній молодіжній політиці. Зокрема, на думку науковців, доцільно фінансувати молодіжні програми за рахунок бюджетів усіх рівнів та проводити конкурси програм, на державному рівні прогнозувати потреби ринку у кваліфікованих спеціалістах та реалізовувати програми розвитку молодіжного підприємництва.

Як ми уже згадували, нормативноправове забезпечення містить прогалину у частині соціального контролю за функціонуванням системи управління соціальним розвитком молоді, що ускладнює формування єдиної системи розвитку потенціалу у сфері івентменеджменту.

Kondov K. V. (2011) з приводу актуальності проблематики соціального контролю слушно зауважує:
«Найважливішою умовою соціальної взаємодії та ефективного функціонування соціальної системи $є$ передбачуваність у діях та поведінці індивідів. Відсутність передбачуваності веде соціальну спільноту до дезорганізації та розпаду. Тому суспільством створюються механізми соціального контролю, які повинні регламентувати та консолідувати діяльність усіх його соціальних суб`єктів, забезпечуючи його стійке, стабільне функціонування, соціальний розвиток та прогрес». На думку Palchenkova V. M. (2015), соціальний контроль - це механізм, за допомогою якого суспільство та його складові елементи (групи, організації) забезпечує дотримання певних умов (обмежень), порушення яких завдає збитків функціонуванню соціальної системи.

у понятті соціального контролю спостерігається поєднання концепцій цілеспрямованого впливу керуючої системи на керовану, а також самоорганізації. Khyzhniak O. V. (2015) локальний соціальний контроль розглядає у якості механізму самоорганізації і самозбереження колективного суб'єкта шляхом встановлення, відтворення в процесі колективної діяльності певного нормативного.

Існує значне розмаїття у визначенні підходів до формування механізмів соціального контролю. Daudova H. V. (2014) зауважує, що більш-менш значуща громадська участь вимагає високого ступеня децентралізації владних і адміністративних повноважень. Децентралізація, на думку вченої, $\epsilon$ однозначно необхідною умовою для громадської участі. Громадська участь може реалізовуватися шляхом прямого контакту громадянина з посадовими особами та за допомогою створення «груп інтересів.

Отже, механізм соціального контролю, як складова системи управління соціальним розвитком молоді може трактуватись у двох аспектах. 3 одного боку - це інституційний формальний механізм, у рамках якого керуюча підсистема (повноважний орган державної влади чи місцевого самоврядування, організації соціальної сфери) здійснює вплив на керовану соціальну підсистему методами соціального впливу для досягнення 
наперед визначених показників соціального розвитку. 3 іншого боку - це неформальна система, у рамках якої зацікавлена частина суспільства (соціальна група) здійснює у визначених законом рамках контроль за динамікою соціального розвитку на засадах самоорганізації. Досягнення високих темпів соціального розвитку молоді вимагає узгодження, гармонізації обох систем. Демократизація суспільства та децентралізація владних повноважень, високий рівень розвитку інформаційних технологій зумовлюють актуальність стимулювання саме другого типу соціального контролю як найбільш ефективного.

Ефективність інституційного соціального контролю у системі управління соціальним розвитком молоді, зокрема, розвитку потенціалу у сфері івентменеджменту, обмежується низкою чинників:

- обмеженість ресурсів (фінансовоматеріальних, кадрових, часу та ін..);

- відсутність мотивації поглибленого вивчення проблем соціального розвитку поза рамками нормативно встановлених пріоритетів та напрямів;

- низька гнучкість у зв'язку з вимушеною діяльністю у рамках нормативних приписів, що не завжди відповідають вимогам часу;

- недостатня готовність використання усього потенціалу сучасних інформаційних технологій;

- комунікативні перешкоди - труднощі у налагодженні комунікацій між об'єктом та суб'єктом управлінського впливу.

Водночас, забезпечення формування i реалізації механізмів неформального соціального контролю вимагає державної підтримки, що може бути реалізована у вигляді:

- грантів, конкурсів на реалізацію проектів соціального контролю у сфері управління соціальним розвитком молоді;

- налагодження міжнародних зв'язків та обміну досвідом 3 державами, де неформальний соціальний контроль $є$ потужним інструментом підвищення ефективності соціального розвитку;
- стимулювання взаємодії державних наукових та освітніх установ, організацій соціальної сфери i недержавних громадських організацій щодо удосконалення методології соціального контролю;

- інформаційна, кадрова, фінансова підтримка (на засадах невтручання та забезпечення незалежності) недержавних громадських організацій, що здійснюють соціальний контроль у системі управління соціальним розвитком;

- забезпечення реалізації правових, політичних, економічних реформ на основі рекомендацій, одержаних 3 незалежних джерел сформованих на основі діяльності суб'єктів неформального соціального контролю.

\section{ВИСНОВКИ}

Проблема соціального розвитку молоді, зокрема, за різними напрямками розвитку потенціалу, традиційно зберігає свою актуальність і у наш час. Конкуренція держав в умовах процесів глобалізації переходить з економічної у соціальну площину. Забезпечення високих макроекономічних показників вже не може вважатись винятковим показником ефективності державної політики. Зміщення парадигми розвитку з економічної у соціальну площину відповідає вимогам часу, гуманістичній, антропоцентричній політиці, що системно проводиться найбільш розвиненими державами світу.

В силу низької поширеності концепцій соціальної відповідальності підприємств на нинішньому етапі в Україні неможлива відмова від державного регулювання процесів, пов'язаних 3 забезпеченням якості життя молоді та розвитку їі потенціалу, зокрема, у сфері івент-менеджменту. Особливо небезпечними загрози, пов'язані з низькою якістю життя є для молоді. Молодь, опиняючись в умовах кризової економіки часто втрачає надію на покращення своїх побутовоматеріальних умов, виїжджає за кордон 
або працевлаштовується у неформальному секторі економіки. Потенціал молоді виявляється розпорошений, незадіяний у процесах виходу економіки 3 кризи та їі прискореного розвитку.

Практичні кроки 3 забезпечення соціального розвитку молоді реалізуються у рамках різноманітних державних

\section{References}

Bondarevska K. V., Fomenko A. O. (2015). Aktualni problemy molodizhnoi zainiatosti v suchasnykh umovakh. Stalyi rozvytok ekonomiky, 1. 110-115. Retrieved from:

http://nbuv.gov.ua/UJRN/sre_2015_1_18

Daudova H. V. (2014). Sotsialnyi kontrol nad diialnistiu orhaniv vlady: polityko-upravlinskyi aspekt. Aktualni problemy derzhavnoho upravlinnia, 1. 156163.

Dmytrash O. P., Smyrychynskyi V. V. (2009). Problemy rozvytku molodizhnoho innovatsiinoho pidpryiemnytstva v Ukraini. Problemy nauky, 2. 10-16.

Khyzhniak O. V. (2015). Lokalnyi sotsialnyi kontrol yak kolektyvna diia (na prykladi kolektyvno-dohovirnoi praktyky). Mizhnarodnyi naukovyi forum: sotsiolohiia, psykholohiia, pedahohika, menedzhment, 18. 21-30.

Kondov K. V. (2011). Sotsialnyi kontrol, yak sotsialnyi fenomen: porivnialna kharakterystyka sotsiolohichnykh нормативно-правових актів і програм, міжнародних програм, грантів тощо. Утім, рівень динаміки соціального розвитку в Україні не відповідає потребам часу, євроінтеграційним прагненням нашої держави. Одним 3 дієвих напрямків підвищення ефективності системи управління соціальним розвитком молоді $\epsilon$ удосконалення механізмів контролю.

pidkhodiv. Hrani: Naukovo-teoretychnyi i hromadsko-politychnyi almanakh, 1. S. 104-109.

Kondov K.V. (2010). Sotsialnyi kontrol yak umova efektyvnoho funktsionuvannia instytutu osvity. Aktualni problemy sotsiolohii, psykholohii, pedahohiky: Zbirnyk naukovykh prats, 11. 149-155

Palchenkova V. M. (2015). Kontseptsiia sotsialnoho kontroliu $\mathrm{V}$ suchasnii teoretyko-pravovii nautsi. Yurydychna nauka, 8. 7-14.

Riven bezrobittia naselennia (za metodolohiieiu MOP) za stattiu, vikovymy hrupamy ta mistsem prozhyvannia. Retrieved from: http://www.ukrstat.gov.ua/operativ/oper ativ2015/rp/eans/eans_u/rbrn_rik15_u.ht $\mathrm{m}$

Zakon Ukrainy «Pro vyshchu osvitu» Retrieved from: http://zakon2.rada.gov.ua/laws/show/15 56-18 